УДК 631.4/18:631.48:631.18

(C) 2015

Крамарьов С. М., доктор сільськогосподарських наук, Крамарьов О. С., магістр

Інститут сільського господарства степової зони НААН України

Христенко А. О., кандидат сільськогосподарських наук

ННЦ Інститут грунтознавста і агрохімії ім. О. Н. Соколовського НААН України

Токмакова Л. М., кандидат сільськогосподарських наук

ДУ Інститут сільськогосподарської мікробіології та агропромислового виробництва НААН України

Жученко С. І., кандидат сільськогосподарських наук,

Сироватко В. А., кандидат біологічних наук,

Цьова Ю. А., аспірант

(науковий керівник - доктор сільськогосподарських наук, професор П. В. Писаренко)

Полтавська державна аграрна академія

Сироватко К. В., інженер

Дніпропетровська філія ДУ Інституту охорони грунтів

\title{
ПОРІВНЯЛЬНА ОЦІНКА ВМІСТУ РУХОМОГО ФОСФОРУ В РІЗНИХ ГЕНЕТИЧНИХ ГОРИЗОНТАХ ЧОРНОЗЕМУ ЗВИЧАЙНОГО
}

\section{Рецензент - доктор сільськогосподарських наук, професор П. В. Писаренко}

\begin{abstract}
Чорноземи звичайні на лесових породах важкого гранулометричного складу Північного Степу Украӥни містять підвищену кількість апатитоподібних сполук. Унаслідок иьього використання будь-яких кислотних методів, у тому числі ГОСТ 26204-91 (метод Чирикова), призводить до істотного итучного завищення оцінки фосфатного стану трунтів (на 40-80 мг $\mathrm{P}_{2} \mathrm{O}_{5} / \kappa 2$ трунту). Для діагностики фосфатного стану даних грунтів, згідно з вимогами нормативних документів Украӥни, слід використовувати наступні стандарти: ДСТУ 4114 (метод Мачігина), ДСТУ 4727 (метод КарпінськогоЗам'ятіної) $і$ ДСТУ ISO 11263 (метод Olsen). Реальна природна забезпеченість орного шару чорноземів звичайних фосфором відповідає межі низької $і$ середньої забезпеченості ичи елементом живлення рослин, щзо підтверджується відомими емпіричними даними про високу ефективність фосфорних добрив на иих трунтах. Підвищеною або високою забезпеченістю фосфором характеризується лише орний шар трунтів, щзо містить залинкові фосфати добрив, а також верхній тумусовий горизонт цілинних трунтів. Тому, для отримання високих врожаӥв із високою якістю на чорноземах звичайних Північного Степу Украӥни необхідно вносити не менше фосфорних добрив, ніж на іниих грунтах країни виходячи з даних трунтової діагностики.
\end{abstract}

Ключові слова: чорнозем звичайний, рухомий фосфор, обробіток трунту.

Постановка проблеми. Поряд з азотом, другим за важливістю елементом мінерального живлення, який в більшості випадків лімітує подаль- ший ріст урожайності зерна всіх без винятків сільськогосподарських культур, $\epsilon$ фосфор. Це пов'язано 3 тим, що в більшості типів грунтів фосфор знаходиться в слаборозчинній мінеральній та недоступній рослинам органічній формах. Майже всі сільськогосподарські культури, лише за виключенням тих їх видів (гречка, люпин, гоpox та ін.), у яких співвідношення $\mathrm{CaO} / \mathrm{P}_{2} \mathrm{O}_{5}$ більше 1,3 , здатні поглинати $\mathrm{P}_{2} \mathrm{O}_{5}$ iз $\mathrm{Ca}_{3}\left(\mathrm{PO}_{4}\right)_{2}$, розчиняючи фосфати своїми ексудатами або вивільняючи фосфор за рахунок інтенсивного поглинання з грунтового розчину катіонів кальцію.

Аналіз останніх досліджень і публікацій, у яких започатковано розв'язання проблеми. Ярі та озимі зернові колосові культури поглинають лише рухому його форму, оскільки вищеназване співвідношення значно менше цього показника (Чириков, 1950). Це пов'язано з тим, що ярі та озимі зернові культури (пшениця, жито, тритикале, ячмінь, кукурудза) слабо засвоюють важкорозчинні сполуки фосфору з грунту, тому вони добре реагують на внесення легкорозчинних форм фосфорних добрив, оскільки вони енергійніше вбирають фосфор і в меншій мірі кальцій. За таких умов наявний надлишок катіонів кальцію хімічно зв'язує рухомий фосфор в слаборозчинні фосфати. Саме через низьку забезпеченість грунтів доступним для рослин фосфором окупність фосфорних добрив досить висока - 


\section{СІЛЬСЬКЕ ГОСПОДАРСТВО. РОСЛИННИЦТВО}

у середньому 1 кг $\mathrm{P}_{2} \mathrm{O}_{5}$ забезпечує приріст 4-5 кг зерна. Внаслідок зниження вмісту фосфору в грунті вже у найближчі роки в Україні зменшення продуктивності сівозмін сягне 2,2 зернової одиниці (Медведєв, 2000). У зв'язку з тим, щоб прослідкувати за змінами, які відбулися з рухомими формами фосфору та порівняти ступінь ї рухомості в чорноземах звичайних на ріллі по відношенню до цілини й виникла необхідність в проведенні досліджень.

Мета: дати порівняльну оцінку вмісту рухомого фосфору в різних генетичних горизонтах чорнозему звичайного за різних систем обробітку грунту.

Методи досліджень. Виконання науководослідної роботи проводили на Ерастівській дослідній станції ДУ Інституту сільського господарства степової зони НААН України, де грунти - чорноземи звичайні мало гумусні важкосуглинкові на лесі.

В орному шарі грунту гумусу міститься 3,8$4,1 \%$ (метод Тюрина), валового азоту $0,22-0,23$, фосфору $0,12-0,13$, калію $2,0-2,1 \%$. Рівень нітратного азоту після 7-денного компостування змінювався від 31 до 52 мг/кг грунту. Рухомого фосфору (за Чириковим) - 110-112 мг/кг, рухомого калію - 105-130 мг/кг, реакція грунтового розчину - нейтральна $\left(\mathrm{pH}_{\text {водн. }}=7,0\right)$.

Для визначення змін, які відбулися з рухомими формами фосфору в чорноземах звичайних під впливом тривалого їх використання в сільськогосподарському виробництві, було зроблено два грунтових розрізи глибиною 2 м, шириною 3 м і довжиною 6 м кожний: перший на цілинній ділянці поблизу села Байківка П'ятихатського району Дніпропетровської області, а другий - на ріллі на відстані 300 м від першого.

Розпочинаючи 3 верхньої частини розрізів, через кожні 5 см по всій глибині відбирали зразки грунту для визначення вмісту в них рухомих форм фосфору, вміст якого визначали за кислотним методом Чирикова (ГОСТ 26204-91) і сольовим методом Карпінського-Зам'ятіної (ДСТУ 4727:2007).

Визначення оптичної густини розчинів проводили на фотоелектроколориметрі КФК-2. Аналізи виконували в трьохкратному аналітичному повторенні.

Результати дослідження. Зміни вмісту загального фосфору в грунті на цілинних та орних ділянках притаманні лише верхньому (0-10 см) шару $-0,164$ i 0,148 \%. Починаючи 3 шару грунту 10-20 см та глибше по профілю, його запаси знаходились на одному рівні. Тому в своїх до- слідженнях основна наша увага зосереджена на рухомих формах фосфору, які в більшості випадках є лімітуючим фактором для росту, розвитку рослин та формування урожайності сільськогосподарських культур.

Вміст рухомого фосфору у досліджуваних ценозах чорнозему звичайного дещо вище рівня динамічної рівноваги фосфатних систем грунтів - 0,17-0,19 мг $\mathrm{P}_{2} \mathrm{O}_{5} /$ л в ріллі і 0,13-0,14 мг $\mathrm{P}_{2} \mathrm{O}_{5} /$ л в шарі 10 см цілини. Для ріллі дане підвищення пояснюється наявністю залишкових фосфатів добрив. Тобто, цей грунт є малоудобреним.

Фосфатний стан нижніх горизонтів обох ценозів практично однаковий і відповідає рівню динамічної рівноваги. Наявність більш високого вмісту рухомого фосфору в окремих шарах грунту $\left(0,10-0,12\right.$ мг $\mathrm{P}_{2} \mathrm{O}_{5} /$ л) створюється за рахунок наявності карбонатів кальцію. Внаслідок появи цих сполук нейтральне значення сольової витяжки (рН-5,8) зсувається в лужну сторону, що підвищує іiі екстрагуючу здатність.

Проведені дослідження дають змогу зробити такі висновки:

1. Чорноземи звичайні на лесових породах важкого гранулометричного складу Північного Степу України містять підвищену кількість апатитоподібних сполук. Унаслідок цього використання будь-яких кислотних методів, в тому числі ГОСТ 26204-91 (метод Чирикова) призводить до істотного штучного завищення оцінки фосфатного стану грунтів (на 40-80 мг $\mathrm{P}_{2} \mathrm{O}_{5} /$ кг грунту ).

2. Для діагностики фосфатного стану даних грунтів, згідно з вимогами нормативних документів України, слід використовувати наступні стандарти: ДСТУ 4114 (метод Мачігина), ДСТУ 4727 (метод Карпінського-Зам'ятіної) і ДСТУ ISO 11263 (метод Olsen).

3. Реальна природна забезпеченість орного шару чорноземів звичайних фосфором відповідає межі низької і середньої забезпеченості цим елементом живлення рослин, що підтверджується відомими емпіричними даними про високу ефективність фосфорних добрив на цих грунтах.

4. Підвищеною або високою забезпеченістю фосфором характеризується лише орний шар грунтів, що містить залишкові фосфати добрив, а також верхній гумусовий горизонт цілинних грунтів. Тому, для отримання високих врожаїв із високою якістю на чорноземах звичайних Північного Степу України необхідно вносити не менше фосфорних добрив, ніж на інших грунтах країни, виходячи $з$ даних грунтової діагностики.

5. Таким чином, дослідження, проведені з використанням сучасних методів грунтової діагностики показали, що реальна природна забезпече- 


\section{СІЛЬСЬКЕ ГОСПОДАРСТВО. РОСЛИННИЦТВО}

ність фосфором чорноземів звичайних Північного Степу України $є$ невисокою, що лімітує отримання високих урожаїв сільськогосподарських

\section{БІБЛІОГРАФІЯ}

1. Якість грунту. Визначення рухомих сполук фосфору за методом Карпінського-Зам'ятіної в модифікації ННЦ ІГА ім. О. Н. Соколовського : ДСТУ 4727-2007. - К. : Держспоживстандарт України, 2008. - 10 с. - (Національний стандарт України).

2. Грунти. Визначення рухомих сполук фосфору і калію за модифікованим методом Мачигіна : ДСТУ 4114-2002. - К. : Державний комітет 3 питань технічного регулювання та споживчої політики, 2002. - 11 с. - (Національний стандарт України).

3. Грунти. Визначення рухомих сполук фосфору і калію за модифікованим методом Чирикова : ДСТУ 4115-2002. - К., 2002. - 5 с. - (Національний стандарт України).

4. Крамарев С. М. Эффективность использования фосфорных удобрений в агроценозах зерновых культур : міжнар. наук.-практ. конф. Наукові доповіді [«Фосфор і калій у землеробстві. Проблеми мікробіологічної мобілізації»] / [С. М. Крамарев, С. В. Красненков, Л. Н. Токмакова и др.]. - Чернігів : КП «Друкарня» № 13. - 2004. C. 56-65.

5. Медведєв B. В. Проблема фосфору в Україні та шляхи іï розв’язання / В. В. Медведєв // Вісник аграрної науки. - 2000. - №7. - С. 82-84.

6. Металіді B. С. Сировинна база фосфатів України / В. С. Металіді, І. В. Щепель // Мінеральні ресурси України. - 1999. - №2. - С. 267-269.

7. Носко Б. С. Фосфатний режим грунтів $\mathrm{i}$ ефективність добрив / Б. С. Носко. - К. : Урожай, 1990. - 153 с.

8. Носко Б. С. Післядія добрив на фосфатний режим чорноземів України / [Б. С. Носко, В. І. Бабинін, Л. М. Бурлакова та ін.] // Вісник аграрної науки. - 2008. - №12. - С. 17-22.

9. Носко Б. С. Влияние состава и свойств почв на результаты определения содержания подвижного фосфора химическими методами / Б. С. Носко, А. А. Христенко // Агрохимия. - 1996. - №4. C. 87-94.

10. Носко Б. С. Фосфорити як джерело живлення сільськогосподарських культур / Б. С. Носко, А. О. Христенко, В.І.Бабинін // Використання культур. Унаслідок цього дані грунти так само потребують внесення фосфорних добрив, як i інші грунти України.

нетрадиційних сировинних ресурсів у сільському господарстві : [зб. наукових статей і доповідей]. - Луцьк : Надстир'я, 1997. - С. 18-20.

11. Носко Б. С. Проблема фосфору в землеробстві України / Б. С. Носко, А. О. Христенко, В. П. Максимова // Вісник аграрної науки. 1999. - №5. - С. 13-16.

12. Полупан I. M. Природний рівень фосфору у грунтах України залежно від їх генетичної природи / І. М. Полупан, В. Б. Соловей, О. В. Коростін // Вісник аграрної науки. - 2008. - №5. C. 14-23.

13. Христенко А. О. Діагностика вмісту рухомих сполук фосфору в грунтах / А. О. Христенко // Вісник аграрної науки. - 1998. - №4. - С. 21-25.

14. Христенко $A$. А. Проблема изучения фосфатного состояния почв / А. А. Христенко // Агрохимия. - 2001. - №6. - С. 89-95.

15. Христенко A. О. Розробка стандарту України на методи визначення рухомих сполук фосфору і калію в грунтах / А. О. Христенко // Вісник аграрної науки. - 2003. - №6. - С. 9-13.

16. Христенко A. О. Вплив складу і властивостей грунтів на результати визначення вмісту рухомого фосфору за методом Мачигіна / А. О. Христенко, Н. П. Копоть, Л. М. Бурлакова // Агрохімія і грунтознавство. - 2001. - №61. - С. 84-92.

17. Христенко А. О. Оцінка фосфатного стану грунтів на основі Міжнародного стандарту / А. О. Христенко, М. С. Лазебна // Вісник аграрної науки. - 2008. - №10. - С. 16-19.

18. Христенко А. О. Рухомість «рухомих» елементів живлення рослин у грунті / А. О. Христенко // Вісник аграрної науки. - 2009. - №8. C. 16-20.

19. Щегров Л. М. Перспективні шляхи виробництва фосфорних добрив в Україні / [Л. М. Щегров, Н. М. Антрапцева, В. П. Кухарь та ін.] // Вісник аграрної науки - 2001 - №9. - С. 13-15.

20. Buehler S., Oberson A., RaoI M. et al. Sequential phosphorus extraction of a 32P-labeled Oxisol under contrasting agricultural systems / S. Buehler, A. Oberson, M. RaoI et al. // Soil Sci. Soc. Am. J. - 2002. - V. 66. - P. 868-877. 